\title{
Hydrodynamics and water quality modelling in a regulated river segment: application on the instream flow definition
}

\author{
Luis Filipe Gomes Lopes a , José S. Antunes Do Carmo ${ }^{\mathrm{b}, *}$, \\ Rui Manuel Vitor Cortes ${ }^{\mathrm{a}}$, Daniel Oliveira ${ }^{\mathrm{a}}$ \\ a University of Trás-os-Montes e Alto Douro, Apartado 1013, 5000-911 Vila Real, Portugal \\ ${ }^{\mathrm{b}}$ Department of Civil Engineering, IMAR, University of Coimbra, Pólo II, Pinhal de Marrocos, 3030-290 Coimbra, Portugal
}

Received 10 December 2002; received in revised form 15 July 2003; accepted 23 July 2003

\begin{abstract}
The aim of this paper is to present a global study on the hydrodynamics, water quality and their influence on aquatic fauna. The case study was conducted on a segment of the Lima river (North Portugal), downstream of the Touvedo dam, which was mainly constructed for hydroelectric power production.

The ISIS FLOW program was used to simulate the hydrodynamics. This model also generates the necessary input data for the water quality simulation using the ISIS QUALITY module. Two basic principles govern the ISIS programs: conservation of mass and momentum.

Water quality parameters (dissolved oxygen and temperature) were simulated for different operational conditions of the Touvedo dam: different discharges (water quantity and duration) and two levels of the water withdrawal, where different water characteristics have been measured.

Another objective was to determine the instream flow for this segment through the Instream Flow Incremental Methodology (IFIM). This technique allowed us to simulate the available habitat for three fish species: brown trout (Salmo trutta), Iberian nase (Chondrostoma polylepis) and chub (Leuciscus carolitertii). Habitat requirements were assessed for different flow regimes (natural versus regulated regime) for 1 year.

We observed a modification in the hydrodynamics and in the water quality as a function of the outflow volume and discharge level by simulating the variation of dissolved oxygen and temperature downstream of the dam.

The response of the fish community to this modification appeared to result in a negative impact on the migratory fish and in the salmonids being replaced by the more tolerant cyprinids.

This work shows that the relation between physical habitat and the targeted aquatic species is a necessary but not sufficient condition for a viable population of aquatic species.
\end{abstract}

(C) 2003 Elsevier B.V. All rights reserved.

Keywords: Water quality; ISIS FLOW; ISIS QUALITY; Instream Flow Incremental Methodology (IFIM); Target-species; Habitat

\footnotetext{
* Corresponding author. Tel.: +351-239-797-153; fax: +351-239-797-152.

E-mail address: jsacarmo@dec.uc.pt (J.S.A. Do Carmo).
}

\section{Introduction}

Patten et al. (1997) showed that the basic interactions in systems with living components are deeply rooted in other systems at both the physical and chemical levels of organization, but biotic systems cannot 


\begin{tabular}{|c|c|}
\hline \multicolumn{2}{|c|}{ Nomenclature } \\
\hline IFIM & $\begin{array}{l}\text { Instream Flow Incremental } \\
\text { Methodology }\end{array}$ \\
\hline PHABSIM & Physical Habitat Simulation \\
\hline RHABSIM & Riverine Habitat Simulation \\
\hline USFWS & $\begin{array}{l}\text { United States Fish and Wildlife } \\
\text { Service }\end{array}$ \\
\hline WUA & Weighted Usable Area \\
\hline$A$ & cross-sectional flow area $\left[\mathrm{L}^{2}\right]$ \\
\hline$C$ & pollutant concentration $\left[\mathrm{ML}^{-3}\right]$ \\
\hline $\operatorname{csi}$ & composite index \\
\hline$D$ & diffusion coefficient $\left[\mathrm{L}^{2} \mathrm{~T}^{-1}\right]$ \\
\hline$g$ & gravitational acceleration $\left[\mathrm{LT}^{-2}\right]$ \\
\hline$H$ & $\begin{array}{l}\text { water surface elevation above } \\
\text { datum }[\mathrm{L}]\end{array}$ \\
\hline K & channel conveyance $\left[\mathrm{L}^{3} \mathrm{~T}^{-1}\right]$ \\
\hline$n$ & $\begin{array}{l}\text { Manning's roughness coefficient } \\
{\left[\mathrm{TL}^{-1 / 3}\right]}\end{array}$ \\
\hline$P$ & wetted perimeter $[\mathrm{L}]$ \\
\hline$q$ & lateral inflow $\left[\mathrm{L}^{3} \mathrm{~T}^{-1} \mathrm{~L}^{-1}\right]$ \\
\hline$Q$ & flow $\left[\mathrm{L}^{3} \mathrm{~T}^{-1}\right]$ \\
\hline R & hydraulic radius $[\mathrm{L}]$ \\
\hline$S$ & $\begin{array}{l}\text { source/sink term; representing } \\
\text { decay, growth, erosion, deposition } \\
{\left[\mathrm{ML}^{-1} \mathrm{~T}^{-1}\right]}\end{array}$ \\
\hline$S_{\mathrm{f}}$ & friction slope \\
\hline $\mathrm{si}_{\mathrm{ci}}$ & $\begin{array}{l}\text { suitability index for the channel } \\
\text { index }\end{array}$ \\
\hline $\mathrm{si}_{\mathrm{d}}$ & suitability index for the depth \\
\hline $\mathrm{si}_{\mathrm{V}}$ & suitability index for the velocity \\
\hline$t$ & time $[\mathrm{T}]$ \\
\hline$u$ & $\begin{array}{l}\text { cross-sectional averaged flow } \\
\text { velocity }\left[\mathrm{LT}^{-1}\right]\end{array}$ \\
\hline$x$ & distance $[\mathrm{L}]$ \\
\hline Greek letters & \\
\hline$\alpha$ & angle of inflow \\
\hline$\beta$ & momentum correction coefficient \\
\hline
\end{tabular}

be reduced totally to physical principles. Straškraba et al. (1999) indicated that higher-level phenomena previously ascribed only to the biological would, are characteristic of the physical world as well, even if there is a difference in how physical principles are expressed at these two levels. In this work we are dealing with aquatic ecosystems. We are trying to describe a global study concerning hydrodynamics, water quality and interaction with the biological component. ISIS programs are used for modelling the physical habitat (flow and water quality), following conservation principles and based on partial differential equations: the Saint-Venant equations are used to illustrate a one-dimensional flow (HR Wallingford, 1997). To express the biological component we have used three target fish species associated with a habitat suitability index.

In fact, the habitat conditions are the principal factor influencing the presence, the abundance and the distribution of organisms in the environment (Southwood, 1977). Several empirical observations indicate that there is a close relation between species extinction and habitat destruction (Noss and Murphy, 1995; Ney-Nifle and Mangel, 1999), and this has been modelled by Nakagiri et al. (2001).

Concerning the fish communities, the system of top-down nested scales (Frissell et al., 1986) is a useful approach since it adopts a hierarchical perspective: the zoogeographical range; drainage basin; river; section or stretch; sequence; macrohabitat or morphological stream unit and, finally, microhabitat. This one is the finest scale, and therefore integrates all the phenomena operating on the higher scales. Thus, the modelling of fish microhabitats is of particular help in understanding the global functioning of aquatic ecosystems (Reyjol et al., 2001). The effects of peaking hydroelectric operations on microhabitats and the re-evaluation of large storage reservoir operations have recently elevated the instream flow management issue to the stream network and river basin scale in the United States (Lubinski, 1992; National Research Council, 1992; Hesse and Sheets, 1993).

All lotic communities are affected by of the flow regime downstream of hydroelectric installations: macroinvertebrate community (Cortes et al., 1998, 2002), and fish communities (Ward and Stanford, 1983; Bain et al., 1988; Langler and Smith, 2001). Regulation change of the flow regime downstream of the water course, reducing the average annual flow, decreasing the seasonal variation, modifying the occurrence of extreme flow events, like the magnitude of floods, and imposing unnatural discharges, generally with a strong daily variation, will all affect the lotic communities.

The main aim of our study was to model the effects of flow regulation on microhabitat use by fish. 
Previous studies have had the same purpose, but in different conditions (Scheidegger and Bain, 1995; Coop, 1996; Pilcher and Copp, 1997; Reyjol et al., 2001). To achieve this goal we adopted the approach established by IFIM (Instream Flow Incremental Methodology), under which the variation of the habitat as a function of time must be defined (habitat time series analysis). In habitat dynamics, the concept of using time series analysis was initially formulated by the Washington Department of Ecology (Clarke, 1976) and by the U.S. Geological Survey (Collings et al., 1972).

Another important goal was to analyse the influence of water quality on habitat availability. This aspect is not considered in studies on instream flow, but it is obvious that eutrophication has a negative impact on the aquatic population. Furthermore, regulation helps to amplify eutrophication symptoms, leading to a dominance of tolerant taxa (Cortes et al., 2002), therefore habitat availability and water quality modelling have to be conducted side by side.

\section{Study area}

The Lima river watershed is located in the Northwest of the Iberian Peninsula (U.E.). It is shared by Portugal and Spain (Fig. 1), and occupies an area of $2525 \mathrm{~km}^{2}$, of which $1170 \mathrm{~km}^{2}$ lies in Portuguese territory (around 47\%). The watershed has a NEE-SWW orientation, with an average width of $19 \mathrm{~km}$ and an av- erage altitude of $450 \mathrm{~m}$. In the uplands, the watershed is dominated by the mountains of the Peneda Gerês where the land cover consists of mosaic of forested areas and natural areas. In the lowland, the topography is more uniform and land the cover is dominated by grassland and arable land.

The Lima watershed has a mean annual rainfall of $1444 \mathrm{~mm}$ and a mean annual evapotranspiration rate of $1000 \mathrm{~mm}$ (1947-1978). In the gauging station of Rabaçal, the mean daily flow was $58 \mathrm{~m}^{3} \mathrm{~s}^{-1}$, with a value of $1.93 \mathrm{~m}^{3} \mathrm{~s}^{-1}$ low flow and $440 \mathrm{~m}^{3} \mathrm{~s}^{-1}$ annual flood.

The Lima river rises in the mountains of S. Mamede, at approximately $950 \mathrm{~m}$ altitude, in the province of Orense, Spain. In Portugal, it flows for $67 \mathrm{~km}$ to its mouth at Viana do Castelo harbour.

The Touvedo hydroelectric power station (Fig. 2) is situated on the Lima river, around $47 \mathrm{~km}$ from its outfall, and is the beginning of the reach to be modelled, which ends in the small town of Ponte da Barca. The Touvedo dam acts as a tailwater reservoir, modulating the high flows released by Alto Lindoso dam (Fig. 2).

\section{Methods}

The ISIS programs were used to simulate the Lima river hydrodynamics and water quality in a segment downstream of the Touvedo dam. The assembly of the ISIS models was developed, and is supported,

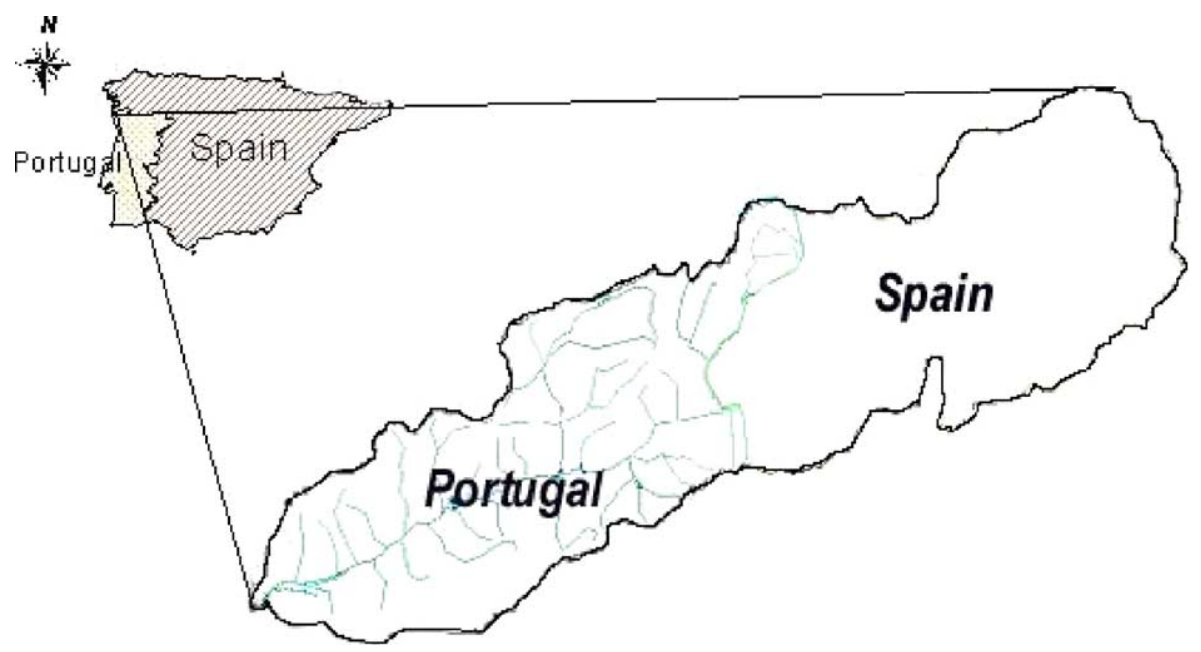

Fig. 1. Location of the Lima river watershed. 


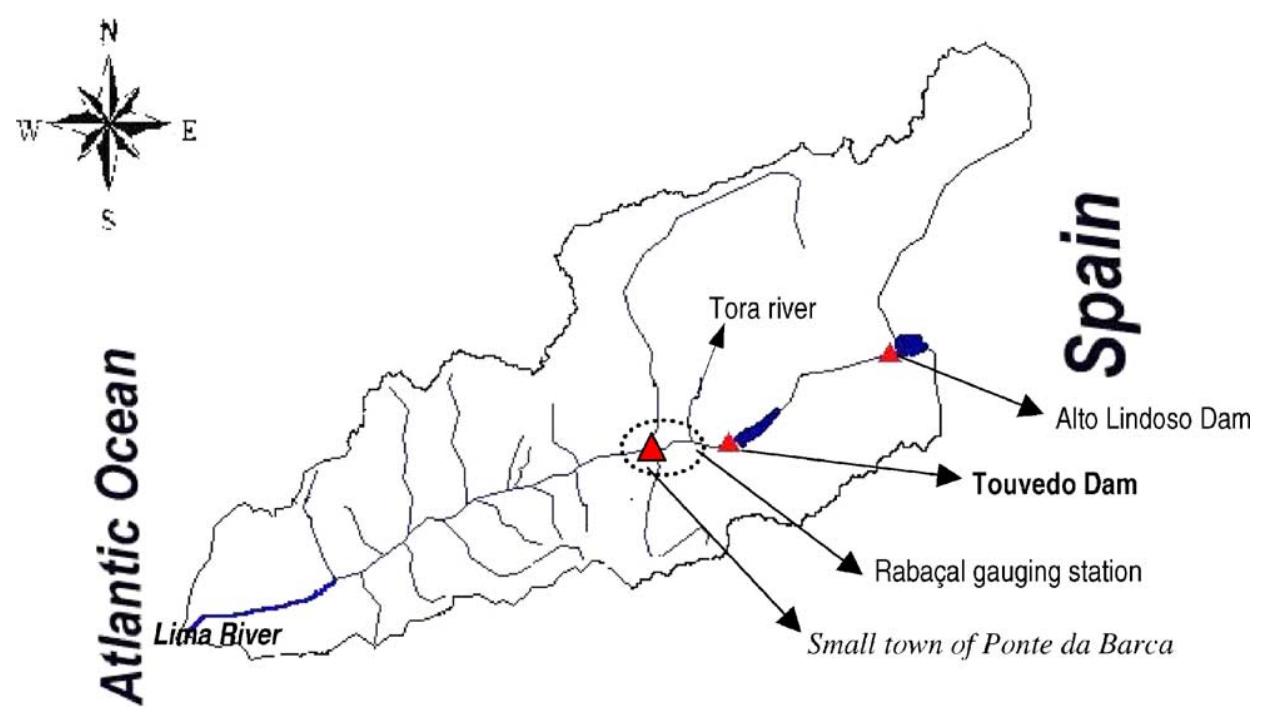

Fig. 2. The stream network of the river Lima and the segment of the Lima river studied: Touvedo-Ponte da Barca.

by Wallingford Software Ltd. and Halcrow Group Ltd.

The IFIM is based on the assumption that the quality and quantity of physical habitat is related to the environmental needs of aquatic animals. The use of the physical habitat is calculated by means of the Physical Habitat Simulation (PHABSIM), which requires the consideration of other factors, because physical habitat is a necessary but not a sufficient condition for the existence of species, or a collection of species; interactions between species and life stages will also influence the state of the ecosystem (Milhous, 1999). The IFIM was developed by the U.S. Fish and Wildlife Service (USFWS) to assess the environmental impacts of water development projects through the quantification of the aquatic habitat (Stalnaker et al., 1995).

The software designated by Riverine Habitat Simulations (RHABSIM), with the acronym of PHABSIM (Payne, 1998), was used to link the stream channel hydraulics with physical habitat utilization by aquatic organisms, primarily fish.

\subsection{Hydrodynamic channel flows}

ISIS FLOW is generally used for modelling steady and unsteady flows in networks of open channels and flood plains. The motion of the water body flowing in open channels can be described by the "shallow water" or Saint-Venant equations, which express the conservation of mass and momentum. Conservation of mass leads to the continuity equation, which establishes balances between the rate of the water rise level and the wedge and prism storages. Conservation of momentum leads to the dynamic equation, which establishes balances between inertia, diffusion, gravity and friction forces. Other forces, such as the wind effects or meanders may also be included, but usually these have only a minor effect. The governing continuity and momentum equations are written:

$$
\begin{aligned}
& \frac{\partial Q}{\partial x}+\frac{\partial A}{\partial t}=q \\
& \frac{\partial Q}{\partial t}+\frac{\partial}{\partial x}\left(\frac{\beta Q^{2}}{A}\right)+g A \frac{\partial H}{\partial x}-g A S_{f}+q \frac{Q}{A} \cos \alpha=0
\end{aligned}
$$

where $Q$ is flow $\left(\mathrm{m}^{3} \mathrm{~s}^{-1}\right), A$ is the cross-sectional flow area $\left(\mathrm{m}^{2}\right), x$ is the distance $(\mathrm{m}), t$ is the time (s), $q$ is lateral inflow $\left(\mathrm{m}^{3} \mathrm{~s}^{-1} \mathrm{~m}^{-1}\right), \beta$ is the momentum correction coefficient, $g$ is the gravitational acceleration $\left(\mathrm{m} \mathrm{s}^{-2}\right), h$ is the water surface elevation above datum (m), $S_{\mathrm{f}}=|Q| Q / K^{2}$ is the friction slope, calculated according to Manning's equation, where $K=A^{2} R^{4 / 3} / n^{2}$ is the channel conveyance, $R=A / P$ is the hydraulic radius (m), $P$ is the wetted perimeter (m), $n$ is Manning's roughness coefficient, and $\alpha$ is the angle of inflow. 
Eqs. (1) and (2) are described in mathematical terms as a pair of one-dimensional non-linear hyperbolic partial differential equations. The solution of any system of differential equations generally depends on the existence, uniqueness and stability conditions. For many applications it is not possible to solve the Saint-Venant equations analytically; hence the need for a numerical solution. The first computational model using an implicit finite differences scheme was implemented by Preissmann (1960). ISIS FLOW employs the Preissmann implicit scheme, and the model boundaries are represented by flow-time, stage-time or stage-flow (rating-curves) relationships, including specific tide curves and hydrological boundaries.

\subsection{Water quality}

Increasing computer speed and the development of new mathematical representations of physical processes have rendered many water quality models obsolete. The ISIS QUALITY program is used for modelling water quality in open channel systems such as rivers and some estuaries. The ISIS FLOW model provides the necessary flow data to be used by ISIS QUALITY.

ISIS QUALITY is capable of modelling a range of water quality variables and processes simultaneously. These include: conservative pollutants; decaying pollutants; coliformes; salt; water temperature; sediment; oxygen balance; water/sediment oxygen interactions; phytoplankton; macrophytes; benthic algae and $\mathrm{pH}$.

ISIS QUALITY is written in a modular fashion so that not all the processes need to be studied at once. However, the river environment is a system in which some of these variables and processes interact, and therefore some modules have to be run together with other features. For instance, phytoplankton growth interacts with dissolved oxygen.

Model boundaries are represented by concentrationtime or concentration-flow relationships. Pollutants can also be introduced into, or removed from, any point in the model.

The transport of pollutants is modelled by a finite difference approximation to the one-dimensional advection-diffusion equation:

$\frac{\partial(C A)}{\partial t}=-\frac{\partial(u C A)}{\partial x}+\frac{\partial}{\partial x}\left(D A \frac{\partial C}{\partial x}\right)+S$ where $C$ is the pollutant concentration $\left(\mathrm{kg} \mathrm{m}^{-3}\right), u$ is the cross-sectional averaged flow velocity $\left(\mathrm{m} \mathrm{s}^{-1}\right)$, $D$ is the diffusion coefficient $\left(\mathrm{m}^{2} \mathrm{~s}^{-1}\right), S$ is the source/sink term; representing decay, growth, erosion, deposition, etc. $\left(\mathrm{kg} \mathrm{m}^{-1} \mathrm{~s}^{-1}\right)$.

All the variables in Eq. (3) represent cross-sectional averaged quantities. This equation is effectively a mass conservation equation with an added source term, $S$. The first term represents the rate of change of pollutant at the point. The second term is called the advection component, and, when combined with the first term, represents the rate of pollutant change in the unit of fluid along the streamline (considering the carrying fluid to be incompressible). This is then balanced by a third term, the diffusion term, which represents the flux of pollutant out of the small unit of fluid travelling with the flow.

Due to the complexity of the river network boundary conditions, Eq. (3) is solved numerically. An explicit implementation of the SMART algorithm, developed by Gaskell and Lau (1988), is used to approximate the advection term.

\subsection{Biological components}

The IFIM is a decision-support system designed to help natural resource managers to determine the benefits or consequences of different water management alternatives. The basis of this technique is the establishment of functions that relate flow to habitat use for target species, which has the acronym of PHABSIM.

Three macrohabitat-level stratifications may be used in an IFIM analysis: drainage basin, networks, and segments. In this work we have used the main channel to stratify and select the segments, which formed the working scale.

The conceptual model for RHABSIM is a depiction of the site as a mosaic of cells. At any particular stream flow, each stream cell has a unique combination of surface area, depth, velocity, substrate and cover. An estimate of microhabitat at a particular discharge, habitat suitability and criteria area are used to define a suitability index for the depth, velocity, cover type and substrate attribute for each stream cell for a life stage of a target species. These univariate suitability indexes are mathematically aggregated to determine the composite suitability of the cells, usually expressed on a scale ranging between 0 and 1 . When 
the composite suitability is multiplied by the surface area of the cell, the product is known as the weighted usable area (WUA). The equation is expressed as:

$\mathrm{WUA}_{Q, S}=\sum_{i=1}^{n}\left(a_{i, Q}\right)\left(\operatorname{csi}_{i, Q, s}\right)$

where $\mathrm{WUA}_{Q, s}$ is the weighted usable area of the reach areas at flow $(Q)$ for a target species $(s), a_{i}$ is the surface area of cell $(i)$, and $\operatorname{csi}_{i, Q, s}$ is the composite of cell $(i)$ at flow $(Q)$ for a target species $(s)$. More precisely, the composite suitability index for the flow $Q$ is the product of the univariate suitabilities for each microhabitat variable:

$\operatorname{csi}=\left(\mathrm{si}_{\mathrm{d}}\right)\left(\mathrm{si}_{\mathrm{v}}\right)\left(\mathrm{si}_{\mathrm{ci}}\right)$

where $\mathrm{si}_{\mathrm{d}}$ is the suitability index for the cell depth, $\mathrm{si}_{\mathrm{v}}$ is the suitability index for the cell velocity, and $\mathrm{si}_{\mathrm{ci}}$ is the suitability index for the channel index (usually cover or substratum) of the cell.

\subsection{Data collection}

\subsubsection{Physical and hydrological data collection}

Spatial resolution is extremely important for obtaining accurate solutions of the Saint-Venant equations. In general, higher Froude numbers and shallow flows require greater spatial resolution. Open channel systems are modelled by taking the channel parameters and computing levels and discharges at a set of discrete cross-sections. Each cross-section is separated from the next by a distance $\Delta x$. Likewise, the solution is carried forward in time by a series of discrete time steps $\Delta t$.

The hydrodynamic flow equations dictate a natural scale for any river reach. The factors influencing the choice of $\Delta x$ and $\Delta t$ are the bed slope, Manning's ' $n$ ' value, minimum discharge, channel top width and water surface curvature.

Several techniques were used to make a cross-section survey of the river Lima, according to the morphological characteristics of the river. A vertical sounding allowed us to determine the horizontal distances, using smaller intervals for the more irregular sections, or longer ones as the sections became more homogenous (Bannister et al., 1994). After the cross-section was determined, a steel cable was stretched between the two margins for stable measurements. For the lower depths, the section survey was carried out by means of the composed levelling method, with a self-levelling, NIKON Automatic Level-AZ. The point level was obtained on a $4 \mathrm{~m}$ telescopic staff. Cross-channel distances were measured using a $30 \mathrm{~m}$ measuring tape. In deeper sections a boat was used to measure these physical parameters. Ground elevations were taken from the national Datum Reference.

Complementary information, for exceptional flows, was obtained from the existing gauges placed at the bridge and the dam.

To determine instream flow requirements, the river segment studied was characterized according to the habitat features: hydraulic variables (velocity and flow stage) and geomorphological channel: substratum (Harrelson et al., 1994).

In the RHABSIM model, a channel cross-section is described as a series of verticals. Each vertical is described by a distance from a known point across the channel, the ground elevation at that distance, and descriptors of structural cover and substratum associated with the locations.

Four cross-sections were established in other four mesohabitats (two pools, a riffle and a run). In these cross-sections, the hydraulic variables (velocity and stage of flow) and the substratum for different discharges in the Touvedo dam at: 4, 20, 50 and $100 \mathrm{~m}^{3} \mathrm{~s}^{-1}$ were measured.

A Buhier Montec xytec 7100 ultrasonic current meter, version 2.00 , was used to measure the water velocity. Series of verticals were established on a pericial base evaluation, which took into account the irregularity of the river bed. In the pools, where the bed is more regular, horizontal intervals of $0.50 \mathrm{~m}$ were chosen, while in other mesohabitats, with less regular characteristics, the intervals were reduced to $0.25 \mathrm{~m}$. In all situations when the depth was less than $0.20 \mathrm{~m}$, only one velocity measurement was carried out. To measure the water surface elevation, a graduated staff was used in each vertical of the transect, replaced by a meter-graduated rope for depths over $4 \mathrm{~m}$. The substratum irregularity was characterized by direct observation of each vertical of the cross-section and it was classified through the index developed by Bovee and Colchnaur (1977).

\subsubsection{Water quality data collection}

The monitoring of water quality consisted of measuring two selected parameters: dissolved oxygen and 
temperature. We collected water samples in July for different flows at eight sites (seven in river Lima and one in the Tora river tributary). Temperature and dissolved oxygen data were obtained in situ using a numerical recording. We also used the water quality data from the local River Board Authorities. This data set consisted of monthly determinations over a 10 -year period. Water quality measurements in the reservoir of the Touvedo were based on Gil (1996).

\subsubsection{Biological data collection}

Successful implementation of IFIM requires the acquisition of accurate and realistic habitat suitability criteria for the target organism(s) being evaluated. This methodology is extremely sensitive to subtle differences in habitat suitability criteria (Bovee et al., 1998).

The use of IFIM requires the selection of at least one target species. Previous studies showed that the stream is essentially colonised by cyprinids, with the Iberian nase and chub predominating (INAG, 1999). Since regulation, these species have replaced most of the original species (salmon and trout). However, since trout still has a residual population, which needs to recover, it was also chosen as a target species, along with the currently dominant cyprinid species, Iberian nase and chub.

We used the Sampling Protocol C (SPC) for the development of habitat suitability criteria (Manly et al., 1993). Habitat use and availability were assessed randomly throughout the study area. Each sample location is identified as being either used or unused by the target organism. Availability is defined as the combination of both used and unused locations. Fish were captured by using a dc current of $500 \mathrm{~V}$ powered by a generation of $2.5 \mathrm{~kW}$. The electrofishing operations were carried out at the four sites in two sessions, one in summer and one in winter.

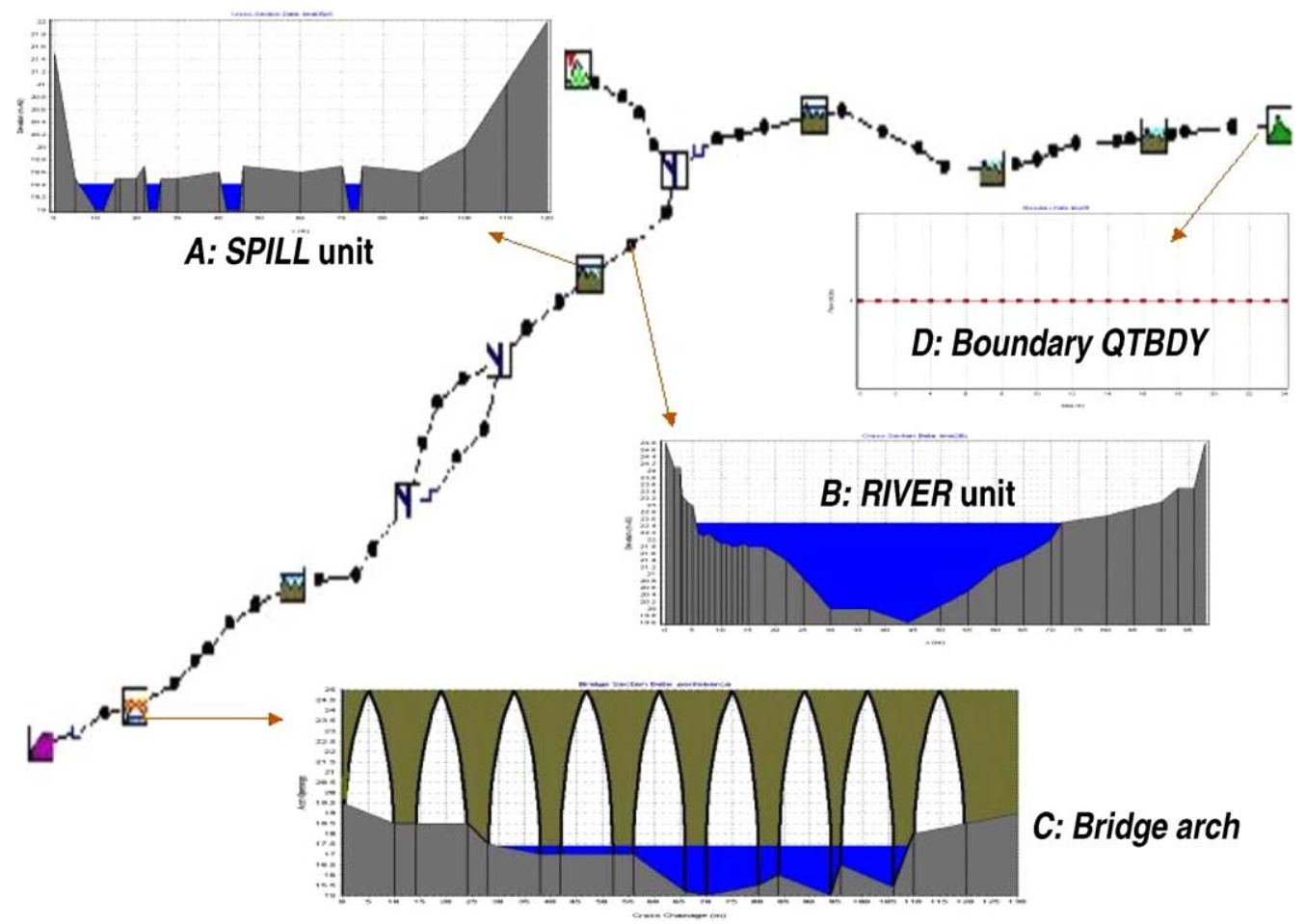

Fig. 3. Outline of the computational model for the Lima river segment: Touvedo-Ponte da Barca, with examples of the internal and external hydraulic units used in the model. (A) SPILL unit, which calculates the flow over irregular weirs associated with traditional fishing; (B) RIVER unit, which simulates the flow in natural channels; (C) Bridge arch, which computes the afflux at arched bridges; (D) Boundary $Q T B D Y$, which models a discharge hydrograph specified as a boundary condition. 


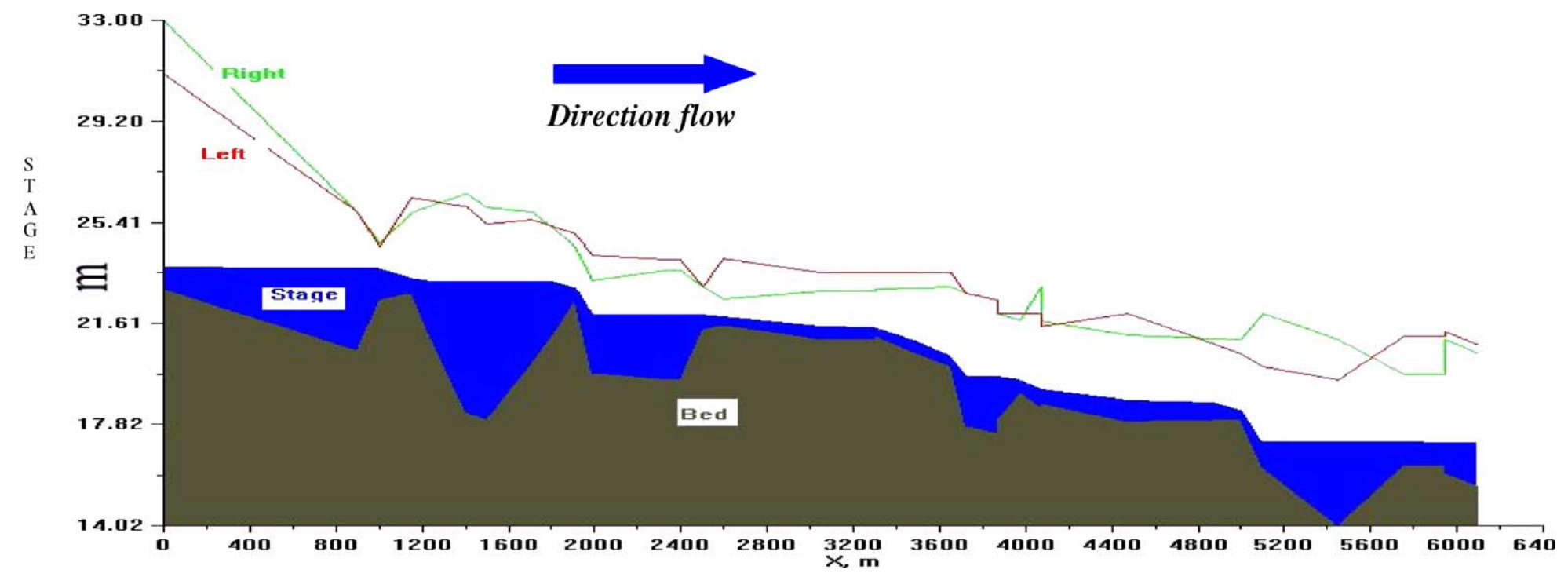

Fig. 4. Longitudinal view of the Touvedo-Ponte da Barca segment, displaying the water stage, for the input flow of $4 \mathrm{~m}^{3} \mathrm{~s}^{-1}$, the left and right banks and bed level. 


\section{Results}

\subsection{Flow and water quality modelling}

Fig. 3 represents the computational model for the segment downstream of the Touvedo dam. In the model construction the system of natural channels was broken into internal and external hydraulic units.

The model is composed of approximately 30 RIVER units, three JUNCTION units, five SPILL units, which compute the flow over irregular weirs associated with traditional fishing, and an ARCHED BRIDGE unit, to model the flow under the Roman bridge of Ponte da Barca. The model has three external units as boundary conditions: FLOW-TIME (QTBDY), which models a discharge hydrograph specified as a boundary condition and represents a discharge hydrograph at the Touvedo dam; a downstream boundary condition FLOW-STAGE (QHBDY), which represents a flow against the stage rating relationship in Ponte da Barca, and a HYDROLOGICAL BOUNDARY, which is a hydrological model for determining runoff from rainfall for a sub-catchment (Tora river), using the United States Soil Conservation Service (US SCS) unit hydrograph method.

For a flow of $4 \mathrm{~m}^{3} \mathrm{~s}^{-1}$, the water surface level reaches $23.4 \mathrm{~m}$ at Touvedo dam and $17.3 \mathrm{~m}$ at Ponte da Barca, representing a slope of approximately $6.1 \mathrm{~m}$ in $6.2 \mathrm{~km}$. This segment thus exhibits a succession of small steps created by the weirs, composed of a pool upstream followed by a small extension riffle.
Fig. 4 represents a longitudinal view of this segment, with the water surface level simulated for the input flow of $4 \mathrm{~m}^{3} \mathrm{~s}^{-1}$ discharged at the Touvedo dam, along with a contribution of $0.5 \mathrm{~m}^{3} \mathrm{~s}^{-1}$ of the Tora river tributary, reaching $4.5 \mathrm{~m}^{3} \mathrm{~s}^{-1}$ at a distance of $3200 \mathrm{~m}$ from origin.

The flow decrease, shown $4000 \mathrm{~m}$ from the origin, can be explained by the existence of a small island in the channel, splitting it into two sub-channels. In Fig. 5, only the flow of the sub-channels, between 3800 and $4000 \mathrm{~m}$, is represented.

The velocity along this segment displays an irregular pattern, as described in Fig. 5: a succession of velocity peaks corresponding to the riffles created by the weirs and more lentic waters associated with the pool areas, having a width similar to the main channel. It is possible to observe that the Ponte da Barca bridge has a relatively reduced influence on the velocity, compared with the effect of the fishing weirs (Fig. 5).

All hydrodynamics simulations have been checked by measured data (existing gauges and Rabaçal gauging station).

We also applied ISIS QUALITY to simulate the selected water quality parameters, temperature and dissolved oxygen, considering the same segment and discharges. Fig. 6 represents the longitudinal variation of these parameters. The initial conditions considered for the water mass of the river Lima are a $20^{\circ} \mathrm{C}$ temperature and $9 \mathrm{mgl}^{-1}$ dissolved oxygen for the whole length of the Touvedo-Ponte da Barca segment. A

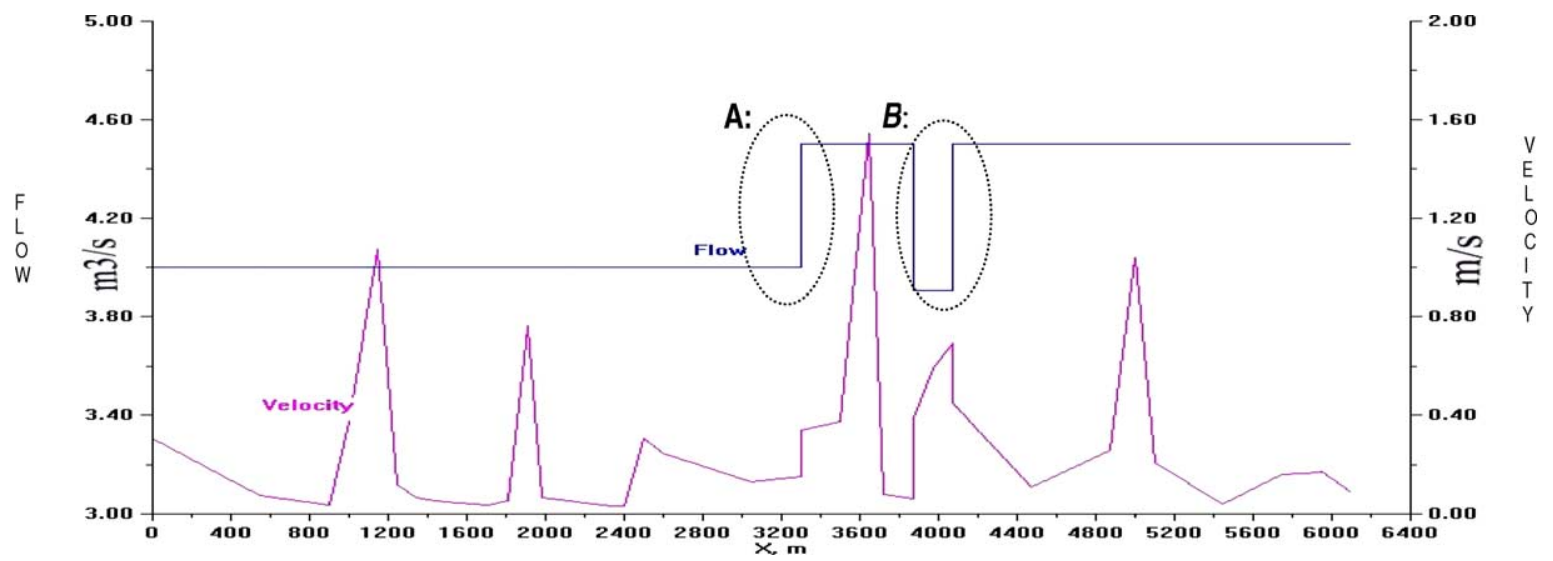

Fig. 5. Longitudinal variation of the flow and water velocity along the Touvedo-Ponte da Barca segment. (A) Input of a $0.5 \mathrm{~m}^{3} \mathrm{~s}^{-1}$ flow on the river Lima from the Tora river tributary. (B) Braided channel effect in the flow. 


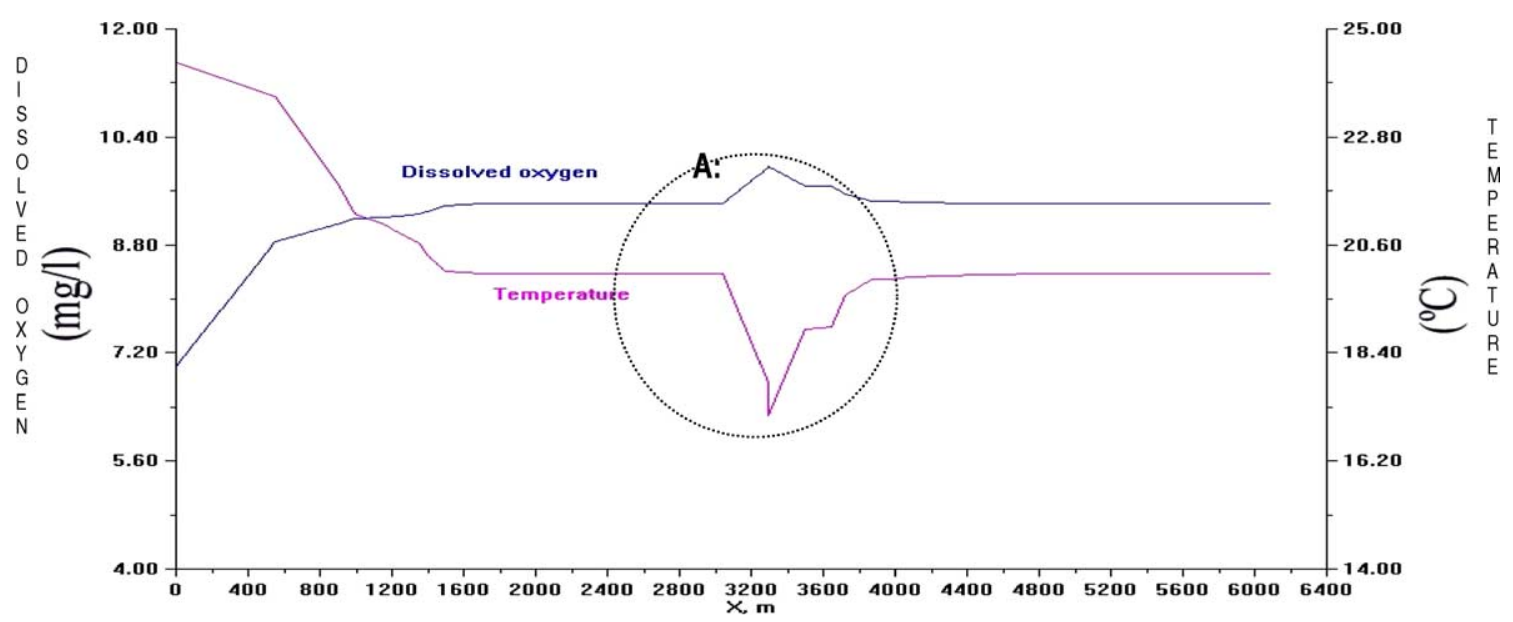

Fig. 6. Longitudinal variation of the water quality parameters, dissolved oxygen and temperature, for a discharge of $4 \mathrm{~m}^{3} \mathrm{~s}^{-1}$ in the Touvedo-Ponte da Barca segment. (A) Particular effect of the Tora river tributary.

discharge of $4 \mathrm{~m}^{3} \mathrm{~s}^{-1}$ at the Touvedo dam was assumed, with the following characteristics: $24.3^{\circ} \mathrm{C}$ temperature and $7 \mathrm{mgl}^{-1}$ dissolved oxygen (values observed by Gil, 1996), in the Touvedo reservoir.

\subsection{Habitat modelling for target-species}

The fish were separated into juveniles and adults according to size (trout $>12 \mathrm{~cm}$ were classed as adults, whilst the length chosen for cyprinids was $9 \mathrm{~cm}$ ). Below these values the fish were classed as juveniles. Comparison of velocity and depth suitability curves for the three target-species and two life states, adults and juvenils, is given in Fig. 7.

The curves shown in Fig. 7 are univariate habitat suitability index curves and were developed for the juvenile and adult stage of each species. They display the habitat utilization separately for water depth and velocity and were obtained after fitting exponential polynomial functions to the frequency histogram data (intervals were set at $20 \mathrm{~cm} \mathrm{~s}^{-1}$ for both parameters). The microhabitat preference for each variable was used to compute the joint preference function, where the same weight was given for the variables of velocity, depth and substrate (where each variable varies between 0 and 1 ).

Two basic principles for the application of IFIM distinguish it from nearly all other approaches to instream flow or instream habitat analysis (Milhous,
1999). The first is the need to define the habitat as a function of the stream discharge (Fig. 8), and the second is the need to define the variation of the habitat as a function of time (Fig. 9). Fig. 8 shows the habitat (WUA) in relation to the stream discharge, of the target-species at different life states during the year.

The same habitat variation is found for the Iberian nase regardless of its stage of development. For chub, on the other hand, there is a differentiation according to the life phases. Each WUA curve for the brown trout presents a specific pattern during the year for the life stage considered. We conclude that the flow values that maximize the WUA vary significantly for each species and life stages.

\subsection{Temporary habitat series}

The design of the IFIM assumes that it is necessary to obtain the pattern of streamflows by integration with the results obtained from PHABSIM in order to carry out an effective instream flow analysis: this is called time series analysis.

The temporary series are built by combining the total habitat area as a function of the flow for a temporary series of flows; we considered days with a temporary unit.

The impact due to the flow regime modification consists of two temporary habitat series within 

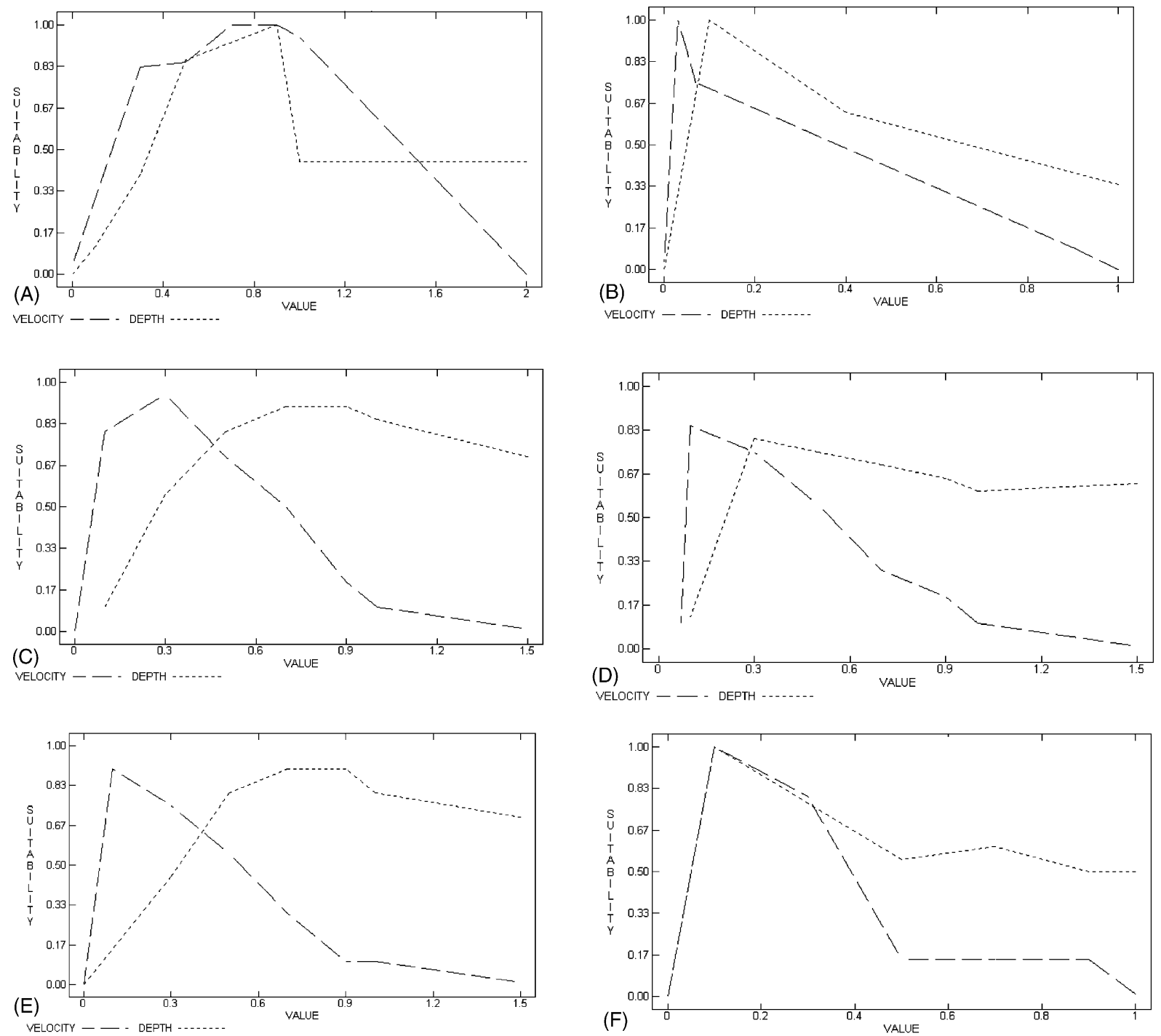

Fig. 7. Habitat suitability criteria (velocity and depth function) for the three target-species. (A) Adult brown trout; (B) juvenile brown trout; (C) adult Iberian nase; (D) juvenile Iberian nase; (E) adult chub; (F) juvenile chub.

(Fig. 9D) and without the project (Fig. 9C). The areas between the two curves are computed. The temporary series allows us to identify the critical periods for a specific phase of the life cycle, the evaluation of potential alterations in fish communities is useful, since each species has a different answer to the flow alterations.

Based on daily averaged flows obtained at the Rabaçal gauging station, the annual hydrograph was computed (Fig. 9A), which may be compared with the reference state corresponding to the situation before the flow regulations.

A daily medium flow annual average of $58 \mathrm{~m}^{3} \mathrm{~s}^{-1}$ is observed, with a minimum of $1.93 \mathrm{~m}^{3} \mathrm{~s}^{-1}$ and a maximum of $440 \mathrm{~m}^{3} \mathrm{~s}^{-1}$ corresponding to the flood peak (Fig. 9A).

Analysis of (Fig. 9B) reveals a critical period, which begins in July (Day 250) and ends in September, where 

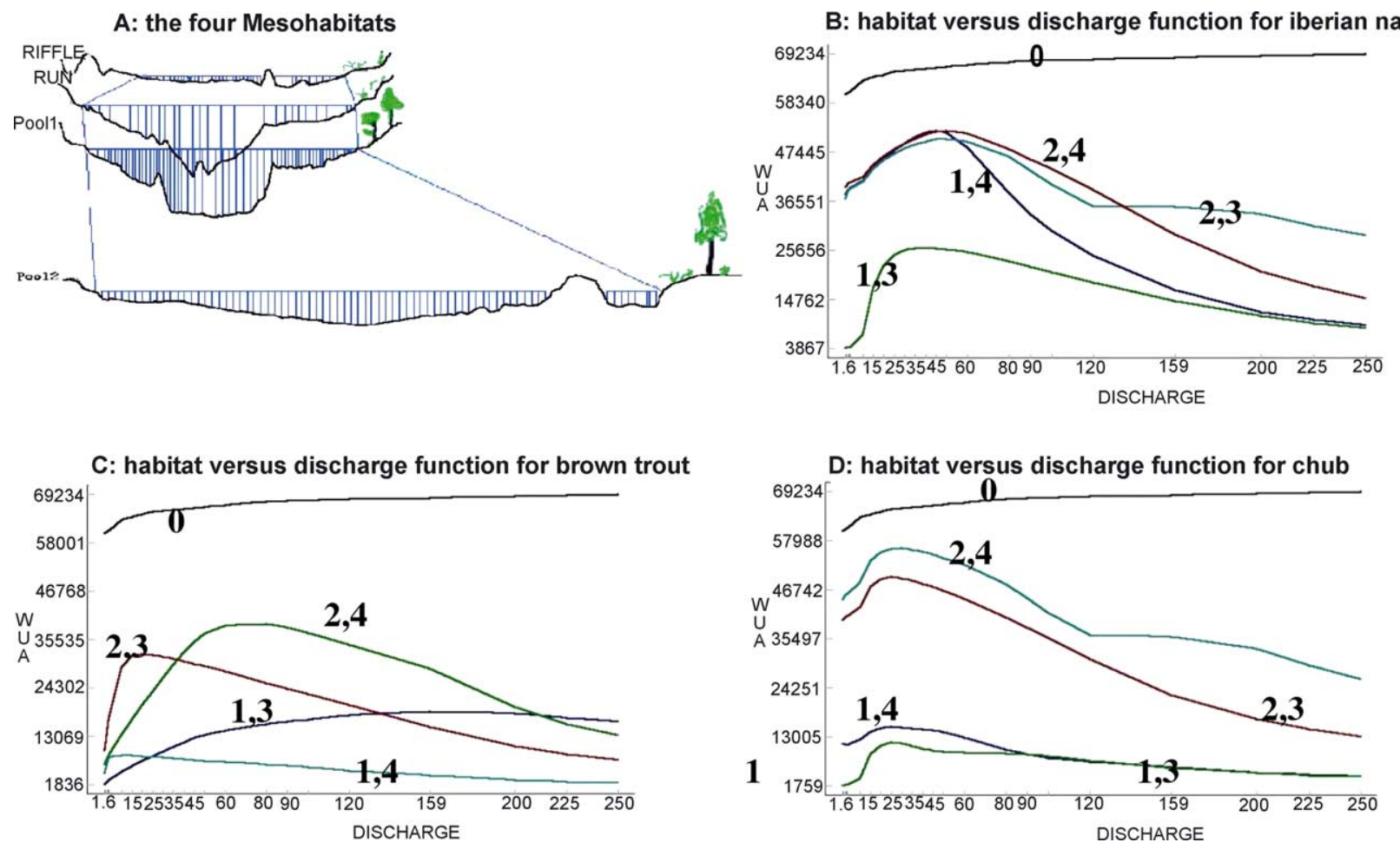

Fig. 8. Habitat (weighted useable area, $\mathrm{m}^{2} / 1000 \mathrm{~m}$ ) vs. discharge for three target-species. (A) Mesohabitats; (B) habitat vs. discharge for Iberian nase; (C) habitat vs. discharge brown trout; (D) habitat vs. discharge function for chub. 0, Total area; 1, Juvenile; 2, Adult; 3, winter/spring; 4, summer/autumn. 


\section{A: Natural flow hydrograph}

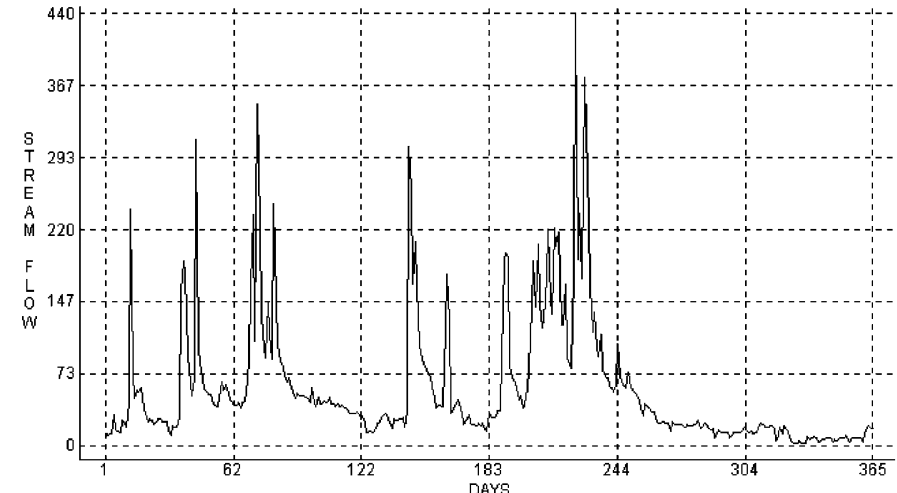

C: Regularized flow hydrograph

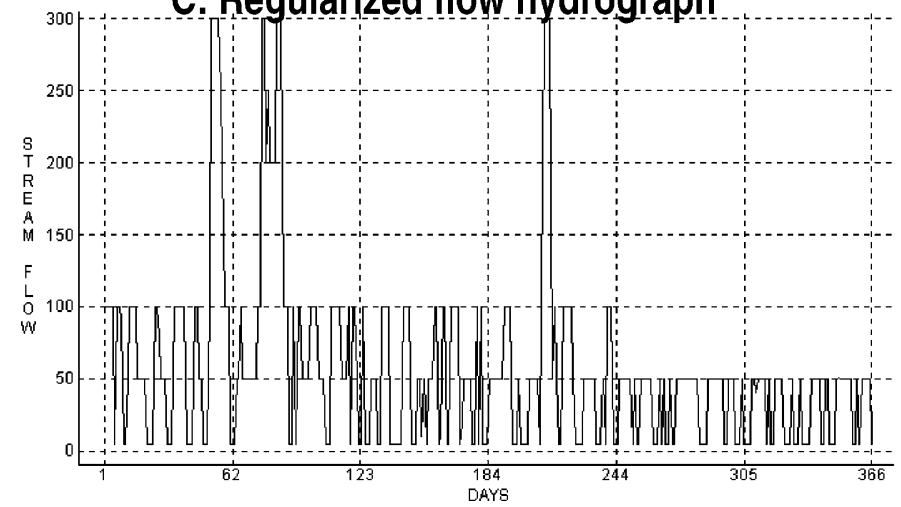

B: WUA in natural flow

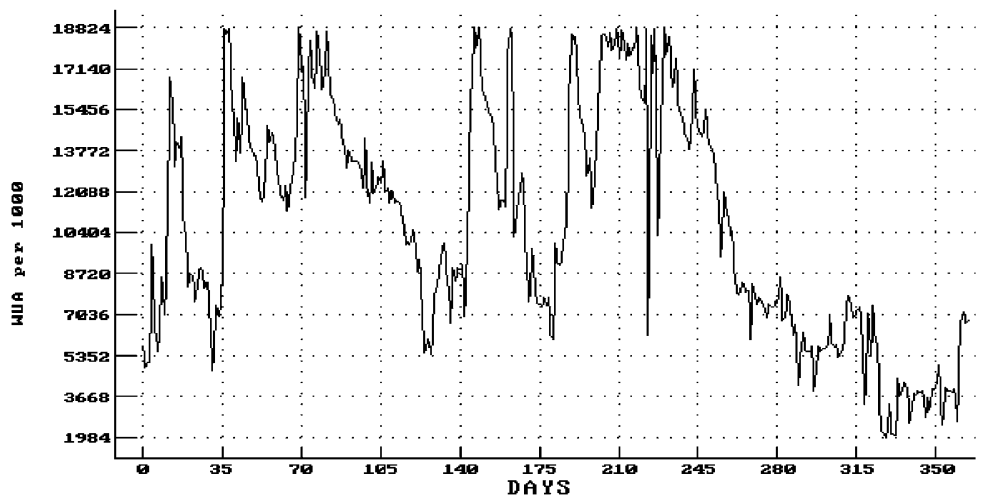

D: WUA in regularized flow

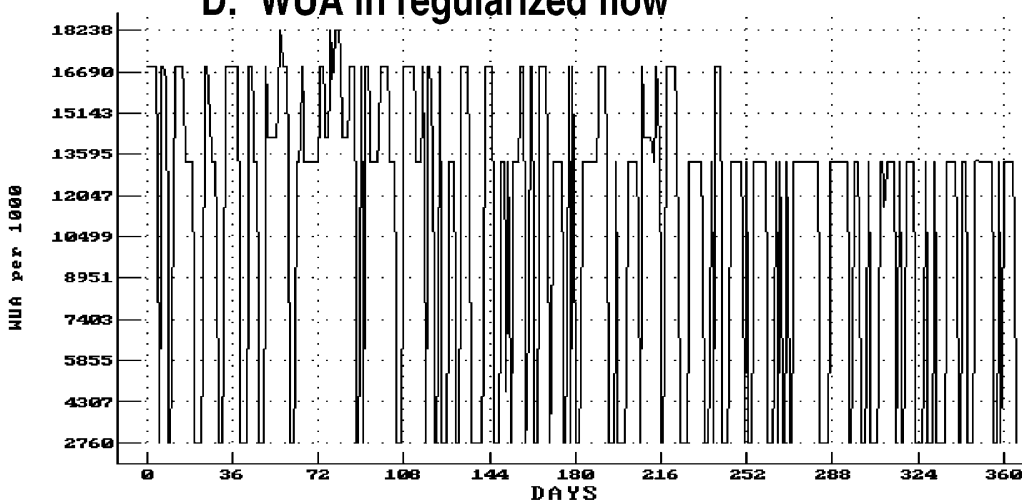

Fig. 9. Temporary habitat series: (A) daily hydrograph in natural regime; (B) daily habitat (WUA) time series for adult brown trout in natural regime; (C) daily hydrograph in regulated regime; (D) daily habitat (WUA) time series for adult brown trout in regulated regime. 
limitations of the available habitat area are noticed for the adult trout.

The regulated regime (Fig. 9C) results in the integration of the discharged flow (50 or $100 \mathrm{~m}^{3} \mathrm{~s}^{-1}$ ) with a $4 \mathrm{~m}^{3} \mathrm{~s}^{-1}$ experimental instream flow and, further, with the flow released by the flood weir. It should be noticed that the flow values and their distribution in time are simulated, given the impossibility of obtaining real values.

There is a minimum of $4 \mathrm{~m}^{3} \mathrm{~s}^{-1}$ instream flow, when a group of generators is not in operation, and this undergoes an abrupt oscillation to 50 or $100 \mathrm{~m}^{3} \mathrm{~s}^{-1}$ when one or two turbines begin to turn. The four peaks correspond to the flood discharges (Fig. 9C).

The Touvedo dam dramatically altered the flow regime downstream, reducing the seasonal flow variation, altering the time of extreme flow occurrence, reducing flood magnitude and imposing unnatural discharges.

No critical period was identified for the brown trout in the regulated regime. The minimum WUA was observed when an environmental flow of $4 \mathrm{~m}^{3} \mathrm{~s}^{-1}$ was discharged at the Touvedo dam. The highest values of WUA were found when $100 \mathrm{~m}^{3} \mathrm{~s}^{-1}$ are discharged by dam. Therefore the optimal value for this species, in terms of the phase of its life cycle and time of the year, is close to this number.
The histogram of total WUA is shown in Fig. 10, for the three species and under the two flow regimes (natural versus regulated).

A non-significant variation in total used habitat (WUA) is observed for all species, from the natural regime to the regulated one. For the adult brown trout winter/spring, we observed an increase of WUA from the natural to the regulated regime. Such an increase is due to the fact that the minimum flow increases in the regulated regime, which corresponds to more available habitat. However, the total WUA does not identify critical periods when the flow limits the sustainability of fish populations.

\subsection{Simulation of water quality and habitat under different discharges}

\subsubsection{Water quality}

A discharge of $4 \mathrm{~m}^{3} \mathrm{~s}^{-1}$ was taken as a reference setting for the Touvedo hydroelectrical operation, which is the summer value of the experimental instream flow. The water withdrawal was placed at the surface, at approximately $0.5 \mathrm{~m}$ depth. The main characteristics of this water mass are temperature, $24.3{ }^{\circ} \mathrm{C}$, and dissolved oxygen, $7 \mathrm{mg} 1^{-1}$ (Fig. 11, time 0:00:00). The flow contribution of the Tora tributary is $0.5 \mathrm{~m}^{3} \mathrm{~s}^{-1}$ and has the following characteristics:

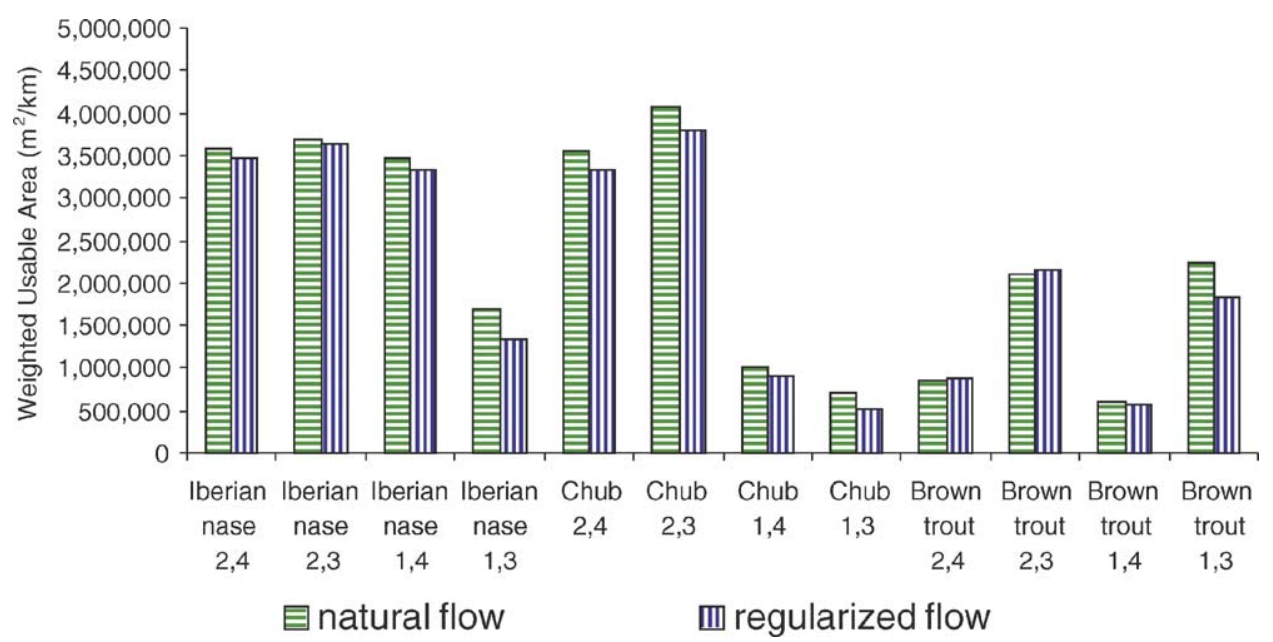

Fig. 10. WUA Histogram for the Iberian nase (Chondrostoma polylepis), chub (Leuciscus caroliterlii) and brown trout (Salmo trutta) in natural and regulated flows: 1 , juvenile; 2 , adult; 3 , winter/spring; 4, summer/autumn. 

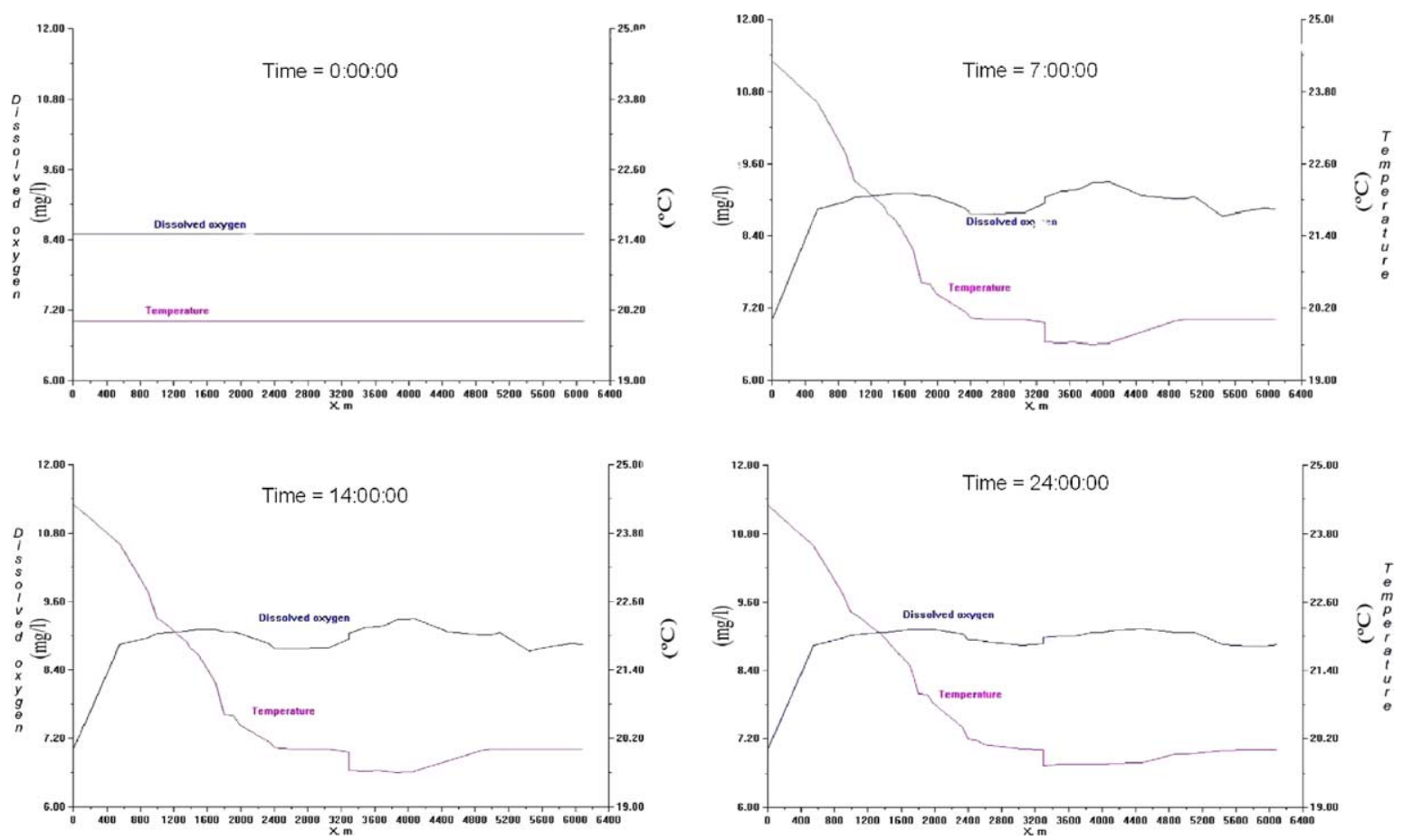

Fig. 11. Spatial and temporal variation of the water quality parameters, dissolved oxygen and temperature, for a discharge of $4 \mathrm{~m}^{3} \mathrm{~s}^{-1}$, and water withdrawal close to the surface $(0.5 \mathrm{~m}$ depth).

temperature $15^{\circ} \mathrm{C}$ and a dissolved oxygen value close to the oxygen saturation point $\left(10.1 \mathrm{mg} \mathrm{l}^{-1}\right)$.

The initial conditions in the water mass of the Touvedo-Ponte da Barca segment are represented in Fig. 11 (time 0:00:00). The following values were considered common to the whole length segment: $20^{\circ} \mathrm{C}$ temperature, and $9 \mathrm{mg}^{-1}$ dissolved oxygen, close to oxygen saturation point.

For the surface water withdrawal, the temperature curve is descending, and the discharge effect is felt for a length of $3000 \mathrm{~m}$. The dissolved oxygen curve displays an inverse behaviour, quickly reaching the saturation point. The water characteristics are influenced by the Tora tributary, which is responsible for the marked drop in temperature observed at $3200 \mathrm{~m}$.

A second scenario with the same upstream hydrograph was considered, but now with the water withdrawal at $20 \mathrm{~m}$ depth. The water mass temperature decreased from 24.3 to $14.5^{\circ} \mathrm{C}$, and the dissolved oxygen fell from 7.0 to $5.2 \mathrm{mg}^{-1}$. The initial conditions considered in the Lima river segment, as well for the Tora tributary inflow, are identical to those for the first scenario. Fig. 12 represents the dissolved oxygen variation and temperature along the Touvedo-Ponte da Barca segment at different times.

In the second situation, the water withdrawal is placed $20 \mathrm{~m}$ depth, where the water characteristics are very different from the ones in the downstream segment, leading to a fall in dissolved oxygen and consequently in water quality. An inverse behaviour is found in the temperature curve, compared with the one obtained for the first scenario. The propagation of this water wave of low quality occurs at low velocity. The contribution of the Tora river tributary is only responsible for immediate variations.

In a more realistic operational scenario, a discharge of $50 \mathrm{~m}^{3} \mathrm{~s}^{-1}$ over a 7 -h period was considered, including two discharges of $4 \mathrm{~m}^{3} \mathrm{~s}^{-1}$. Fig. 13 represents the upstream hydrograph that corresponds to this scenario.

As discharges of 4 and $50 \mathrm{~m}^{3} \mathrm{~s}^{-1}$ take place at different depths, these being 0.5 and $20 \mathrm{~m}$, respectively, the following water characteristics are expected (Fig. 14): a flow of $4 \mathrm{~m}^{3} \mathrm{~s}^{-1}$ at a temperature of $24.3^{\circ} \mathrm{C}$, falling to $14.5^{\circ} \mathrm{C}$ for a $50 \mathrm{~m}^{3} \mathrm{~s}^{-1}$ low. 

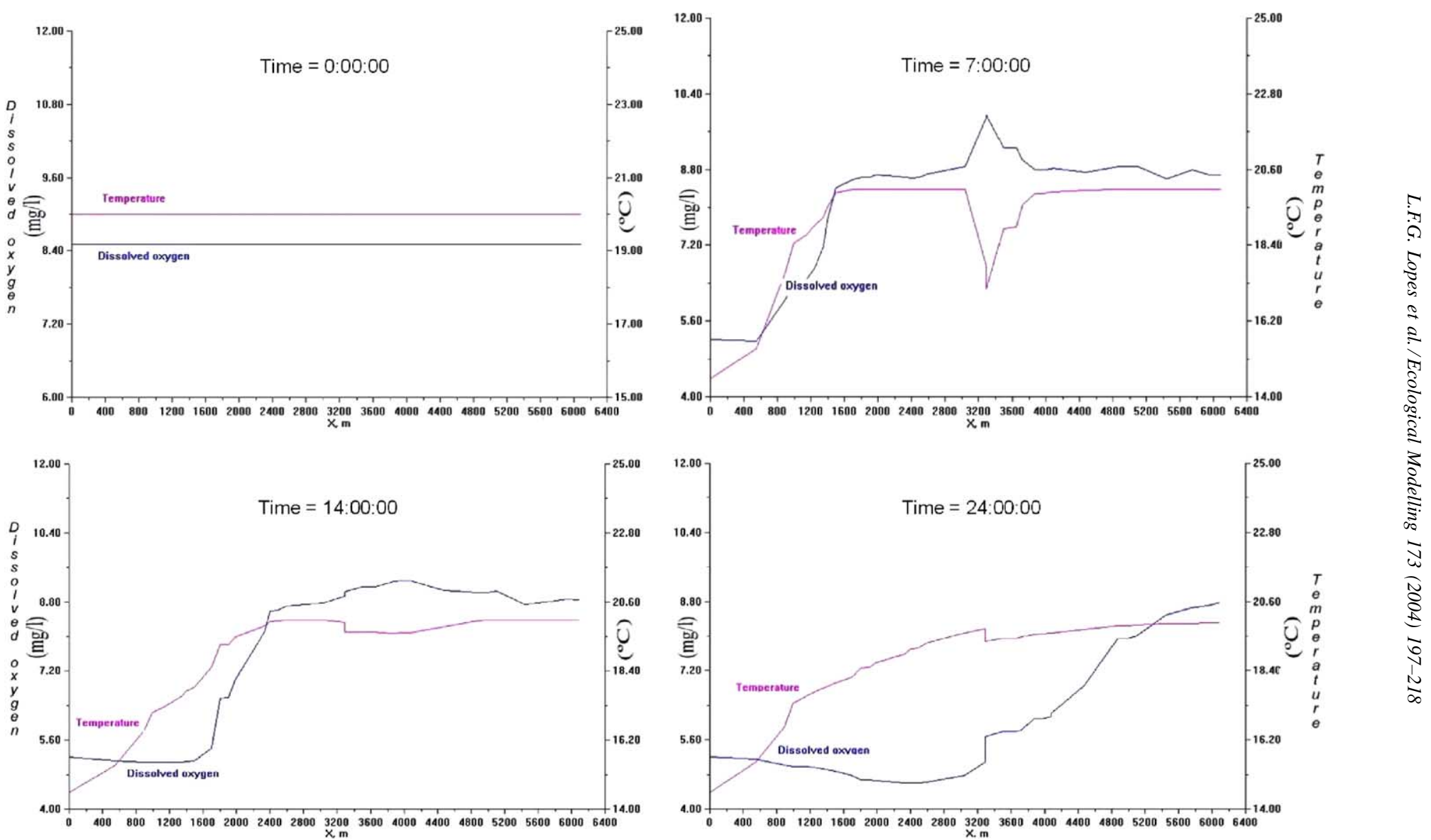

Fig. 12. Spatial and temporal variation of the water quality parameters, dissolved oxygen and temperature, for a discharge of $4 \mathrm{~m}^{3} \mathrm{~s}^{-1}$, with the water withdrawal at $20 \mathrm{~m}$ depth. 


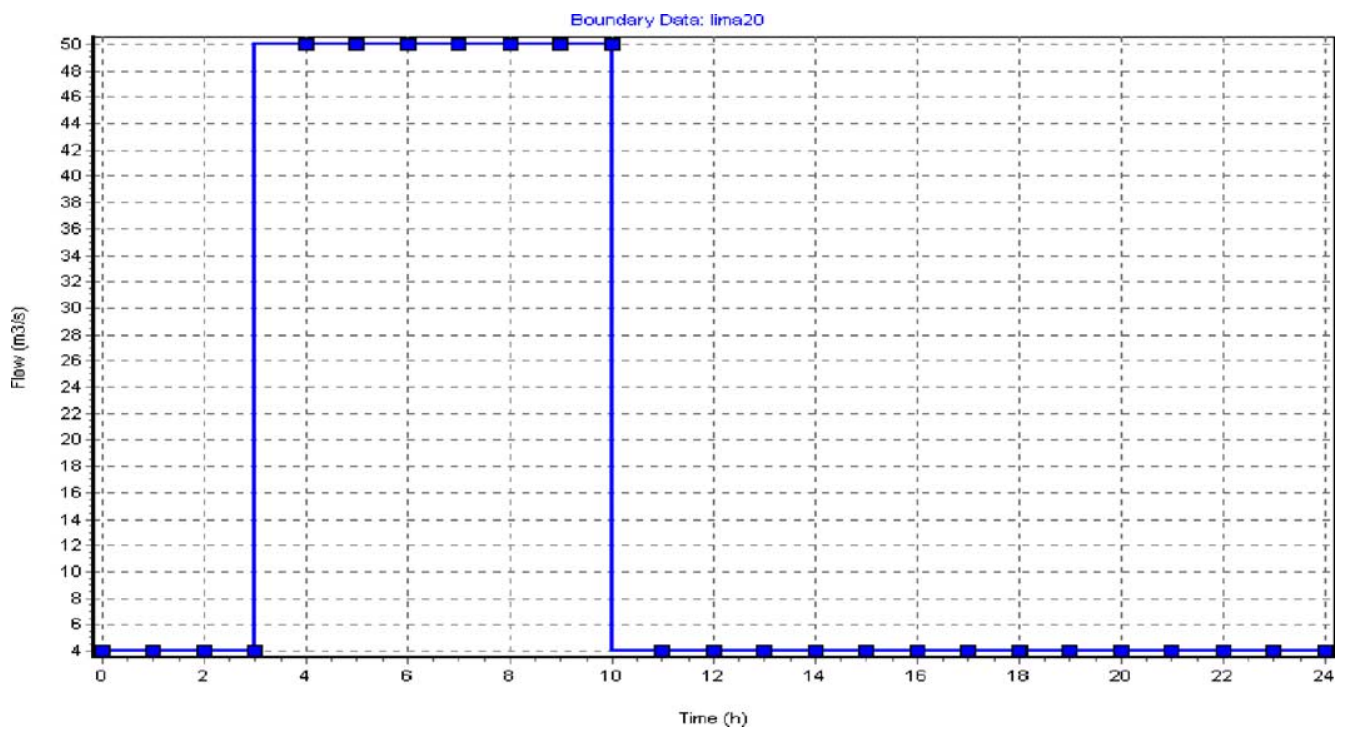

Fig. 13. Upstream hydrograph for a discharge of $50 \mathrm{~m}^{3} \mathrm{~s}^{-1}$ over a 7 -h period at Touvedo.

Likewise, we would have a value of $7 \mathrm{mg}^{-1}$ dissolved oxygen for the $4 \mathrm{~m}^{3} \mathrm{~s}^{-1}$ flow, falling to $5.2 \mathrm{mg} \mathrm{l}^{-1}$ for the $50 \mathrm{~m}^{3} \mathrm{~s}^{-1}$ discharge.

The initial conditions and the water characteristics of the Tora river tributary are identical to the ones for the previous scenarios.

Fig. 14 represents the initial conditions (time 0:00:00) and values of dissolved oxygen and temperature before the discharge of $50 \mathrm{~m}^{3} \mathrm{~s}^{-1}$ (time 2:00:00). It also represents the abrupt change in the water temperature and dissolved oxygen caused by the beginning of the $50 \mathrm{~m}^{3} \mathrm{~s}^{-1}$ discharge (time 7:00:00), and other abrupt alterations due to the end of $50 \mathrm{~m}^{3} \mathrm{~s}^{-1}$ flow and the beginning of $4 \mathrm{~m}^{3} \mathrm{~s}^{-1}$ discharge (time 12:00:00).

This third simulation corresponds to a more complex situation, where an abrupt hydrological and water quality variation is detected. It reflects an obvious drop in the water temperature and dissolved oxygen, which quickly extends to the whole segment, due to the large amount of water discharged. Seven hours after the beginning of the $50 \mathrm{~m}^{3} \mathrm{~s}^{-1}$ discharge, the water mass of the entire segment presents low dissolved oxygen values. The dissolved oxygen recovery during the $4 \mathrm{~m}^{3} \mathrm{~s}^{-1}$ discharge is very slow, as can be seen from Fig. 14. The order of magnitude between the two flows is very different; in fact,
$50 \mathrm{~m}^{3} \mathrm{~s}^{-1}$ is about 12 times more than $4 \mathrm{~m}^{3} \mathrm{~s}^{-1}$. During the $50 \mathrm{~m}^{3} \mathrm{~s}^{-1}$ discharge the effect of the Tora tributary in the river Lima water quality was not noticeable, due to its reduced contribution to the total flow.

\subsubsection{Physical habitat}

To understand the physical habitat variation under the different operational conditions of the Touvedo dam we developed a habitat time series for the three previous settings. Fig. 15 only gives the WUA for the three target species and respective stages of life.

As we already observed, the situation defined by the third simulation produced more significant changes in the WUA. This is due to a combination of flows, which have a more marked impact on the habitats than each separate flow.

\section{Discussion}

The main conclusion with respect to the hydrodynamic component is: the discharges' effects downstream of the dam were felt mainly in a segment of about $6000 \mathrm{~m}$. This segment is populated by countless fishing dams that influence the hydrodynamics, and are difficult to model without resorting to the internal 

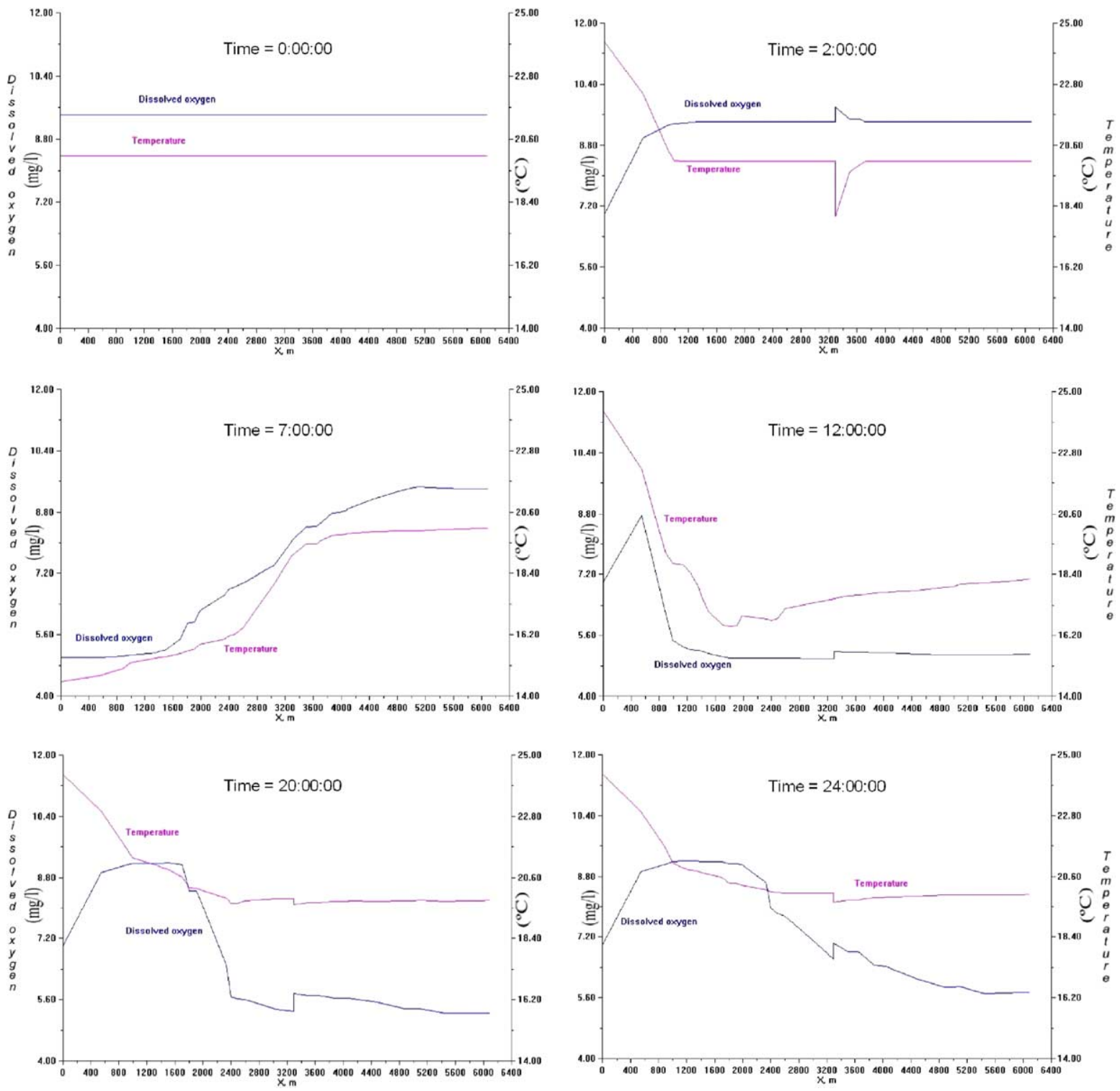

Fig. 14. Spatial and temporal variation of the water quality parameters, dissolved oxygen and temperature, considering a $50 \mathrm{~m}^{3} \mathrm{~s}^{-1}$ discharge over a 7-h period, including two discharges of $4 \mathrm{~m}^{3} \mathrm{~s}^{-1}$.

\section{SPILL unit.}

The hydrodynamics influences the water quality, since it is a function of the outflow and stage of discharge.

The Touvedo dam reservoir registered a vertical difference of about $10^{\circ} \mathrm{C}$, which has a considerable influence on the discharged water characteristics downstream of the reservoir: For the same flow of
$4 \mathrm{~m}^{3} \mathrm{~s}^{-1}$, a very significant difference was found in the water quality downstream of the dam.

We also concluded that changes in the water quality caused by a $50 \mathrm{~m}^{3} \mathrm{~s}^{-1}$ discharge are felt more quickly and in a larger stretch of the river Lima than those caused by a $4 \mathrm{~m}^{3} \mathrm{~s}^{-1}$ discharge. More important than the flow is the level of the water withdrawal. For water withdrawals occurring at shallower depths (close to 


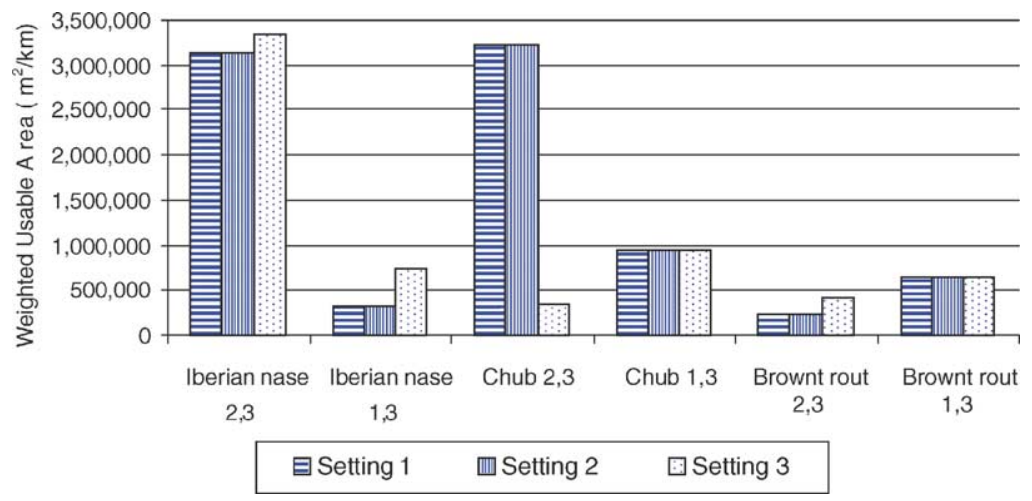

Fig. 15. WUA histogram for the Iberian nase, chub and brown trout in three scenarios of Touvedo dam operations: 1 , juvenile; 2 , adult; 3, winter/spring.

the surface), the water discharged showed a higher quality (more oxygen) when compared to the water withdrawal occurring at greater depths.

The IFIM traced the impact on the biological component through the habitat suitability criteria for the target species. The most relevant fact, but one which was contradictory, was the uniformity of WUA in spite of different flow regimes (natural versus regulated) and operational conditions at the Touvedo dam. Observed differences among patterns of microhabitat use in natural flow and regulated flow must be linked to microhabitat availability. Opposite patterns obtained in natural and regulated flow may not reflect the real preferences of these species, but only the use of the available microhabitat conditions. Nevertheless, the persistence of some tendencies in natural and regulated flows may reflect the real preferences of the species (Baldridge and Amos, 1982; Bovee, 1982; Raleigh et al., 1986; Belaud et al., 1989). The determination of habitat suitability using the PHABSIM model was required, first through observation of the physical characteristics in the spots where the fish were observed, following a random survey by electrofishing. These observations tend to assume that the conditions observed in the vicinities of the captured fish are those most preferred. However, as Lambert (1987) points out, if insufficient "ideal" habitat is available in the natural setting the fish might have been occupying a less-than-ideal habitat, resulting in biased suitability criteria, which do not reflect the target species' preference. Univariate curves were the next criteria selected for expressing habitat suitability (Fig. 7). The tails of the curve are designed to encompass the range of the environmental variables and the narrow peak represents the optimum. However, while their use is very familiar, some criticism has nevertheless been expressed (e.g. Morhardt and Mesick, 1988), mainly because when calculating the composite suitability index the univariate curves treat variables independently, disregarding interactions between variables. Furthermore, a large area of low-quality habitat can produce the same WUA as a small amount of high quality habitat.

Some of the previous considerations explain why there are often weak relationships between the WUA for a single population at different times for the same stream reach, especially if there are important flow variations (e.g. Gowan, 1984; Anderson, 1984). To improve the correlation between WUA fish populations information is frequently collected on the available habitat concurrently with the above-mentioned data concerning fish utilization of the different habitats (Reyjol et al., 2001). Consequently, habitat availability is used to modify the observed information on the microhabitat at the fish location. But even with this correction, it is obvious that the instant assessment of the WUA can hardly be correlated to target species whose standing density or biomass is the result of both the generally stochastic variation of the habitat conditions during the previous stages of development and of biotic factors (such as inter- and intra-specific interactions). Another correction could be made by using different weighting factors for calculating the joint preference function, instead of the same relative importance, as was used here. Such differences 
between factors can be empirically derived and are useful for taking into account the bottleneck imposed by a specific factor, but they require more information about the ecology of each population in the ecosystem.

In addition, an assessment based on calculations of the WUA must be made with great care, because managers assume that areas of the stream not actually occupied by fish can be eliminated without affecting the fish population, even adopting stream flows lower than the ones occurring naturally. This can be a consequence, for instance, of a high contamination load impacting strongly on fish communities. WUA estimation is not an end in itself and needs to be validated by analysing fish dynamics over time and by taking into consideration both the physical variables included in the PHABSIM model (depth, velocity and substrate) and the most relevant parameters linked to water quality. Therefore, it is best to run water quality models together with flow simulation and to compare the results with the WUA calculations. This approach was attempted in this work but, as already mentioned, these models need further confirmation by carrying out biological surveys. Furthermore, the PHABSIM software also accepts a wider range of variables, provided that they are related to hydraulics, and these, too, may help to improve the WUA results, especially in relation to fish behaviour. In fact, as Bovee et al. (1998) have already pointed out, the notion that only microhabitat variables can be used (depth, velocity and substrate) is a mis-conception, since it accepts other microhabitat variables such as nose and adjacent velocity, cover type, distance from shore, proximity to another habitat type, shear stress or Froude number.

Adult fish populations are determined by recruitment, which is strongly correlated with the amount of habitat available for the early stages of the species. Habitat bottlenecks usually affect recruitment directly, via habitat types related to the production and survival of eggs, larvae and fry, or indirectly, related to the growth rates of juveniles or to the microhabitat for invertebrate food supplies (Stalnaker et al., 1995). Only by predicting the main factors that affect fish survival and growth (especially during their critical periods of development), incorporating appropriate time series, from available habitat to water quality, followed by the field validation mentioned earlier, can we make a better judgement about the instream flow that does not militate against the sustainability of the selected aquatic species or guilds of species. Therefore the values obtained for the WUA in Fig. 9 (natural versus regularized flows) have to be treated with caution since there is no automatic adaptation of fish species to changes of flow. This is especially evident in regulated streams like the Lima river where the irregularity of flow in natural versus regularized conditions (Fig. 9) imposes different adaptations (e.g. time lags) or bottlenecks that are not maintained. Unfortunately, most of the time this is an impossible task, especially when time is scarce, as it is in most of the EIA studies. We must therefore use different models that cover a wider ecological spectrum instead of just a single technique. But because each of these models (like ISIS FLOW or ISIS QUALITY and PHABSIM/IFIM) use different assumptions, algorithms and variables it is necessary to run them side by side and to compare the results, together with the opinion of experts on the wildlife ecology and literature about the specific ecosystem. Only in this way it is possible to integrate all the information and to avoid simplistic conclusions, which may be ecologically devastating when decisions have to be made, since a multitude of approaches, models and tools will have been used, each developed to satisfy a specific need.

The integration of flow and quality models with local biological information proved to be a multifaceted mechanism for assessing the operation of the Touvedo dam. We have demonstrated that the relation between physical habitat and aquatic populations is not simple, but that it must include other aspects of the ecosystem and the history of the streamflows (Milhous, 1999). Finally, we emphasize that the modelling approaches, the system (habitat) simulation and living components all help towards understanding ecosystem functioning, and may well help us to define management programs for river regulation.

The operational conditions imposed by a dam (Touvedo hydropower) altered the hydrodynamics and the water quality. Consequently, the composition of the fish population was changed, since salmonids and migratory fish declined, and were replaced by tolerant cyprinids. Each species exhibited different resilience curves, according to their capacity to develop more satisfactory adaptations to intense water level fluctuations (Bunt et al., 1999), or depending on their reproductive characteristics. Monitoring of these communities is essential for the instream flow 
setting. The use of the physical habitat calculated by RHABSIM requires consideration of other factors, because physical habitat is a necessary but not a sufficient condition for the existence of a species or a collection of species. Furthermore, interactions between species and life stages will influence the state of the ecosystem. In future work we intend to develop an integrated approach to water quality parameters and the physical habitat for the same target-species.

\section{References}

Anderson, R.M., 1984. Fish flow investigation. In: Ruch, J.R. (Ed.), Instream Fisheries Investigations. Colorado Division of Wildlife, Fort Collins Colorado, pp. 1-25.

Bain, M.B., Hearne, J.T., Bokke, H.E., 1988. Stream regulation and fish community structure. Ecology 69, 382-392.

Baldridge, J.E., Amos, D., 1982. A technique for determining fish habitat suitability criteria: a comparison between habitat utilization and habitat availability. In: Proceedings of Symposium on Acquisition and Utilisation of Aquatic Habitat Inventory Information. Western Division of American Fisheries Society, Bethesda, MD, pp. 251-258.

Bannister, A., Raymond, S., Baker, R., 1994. Surveying, sixth ed. Longman Scientific \& Technical, London.

Belaud, A., Chaveroche, P., Lim, P., Sabaton, C., 1989. Probabilityof-use curves applied to brown trout (Salmo trutta fario L.) in rivers of southern France. Regul. Rivers: Res. Mngnage. 3, 321-336.

Bovee, K.D., Colchnaur T., 1977. Development and Evaluation of Weighted Criteria, Probability-of-Use Curves for Instream Flow Assessments: Fisheries. Instream Flow Information Paper No. 3.

Bovee, K.D., 1982. A guide to stream habitat analysis using Instream Flow Incremental Methodology. Instream Flow Information Paper No. 12, FWS/OBS 82/26, U.S. Fish and Wildlife Service, Washington, DC.

Bovee, K.D., Lamb, B., Bartholow, J., Stalnaker, C., Taylor, J., Henriksen, J., 1998. Stream Habitat Analysis Using the Instream Flow Incremental Methodology. U.S. Geological Survey, Biological Resources Division, 130 pp.

Bunt, C.M., Cooke, S.J., Katopodis, C., McKinley, S., 1999. Movement and summer habitat of brown trout (Salmo trutta) below a pulsed discharge hydroelectric generation station. Regul. Rivers: Res. Manage. 15, 395-403.

Clarke, C., 1976. An approach to the analysis of minimum flows: case of the cedar basin. Office Report No. 47. Water Resources Analysis and Information Section, Department of Ecology, Olympia, Washington.

Collings, M.R., Smith, R.W., Higgins, G.T., 1972. The hydrology of four streams in western Washington as related to several Pacific salmon species. U.S. Geological Survey Water Supply Paper 1968. 109 pp.
Coop, G.H., 1996. Microhabitat used of fish larvae and juveniles in a highly regulated section of the River Great Ouse. Invited paper for special issue of Regul. Riv.

Cortes, R.M.V., Ferreira, M.T., Oliveira, S.V., Godinho, F., 1998. Contrasting impact of small dams on the macroinvertebrates of two Iberian mountain rivers. Hydrobiologia 389, 51-61.

Cortes, R.M.V., Ferreira, M.T., Oliveira, S.V., Oliveira, D., 2002. Macroinvertebrate community structure in a regulated river segment with different flow conditions. River Res. Appl. 18, 367-382.

Frissell, C.A., Liss, W.J., Warren, C.E., Hurley, M.D., 1986. A hierarchical framework for stream habitat classification: viewing streams in a watershed context. Environ. Manage. 10, 199-214.

Gaskell, P.H., Lau, A.K.C., 1988. Curvature-compensated convective transport: SMART. A new boundedness-preserving transport algorithm. Int. Meth. Fluids 8, 617-641.

Gil, L., 1996. Caracterização da água da albufeira do Touvedo. LABELEC, Departamento do Meio Ambiente e Química Aplicada-MA.

Gowan, C., 1984. The impacts of irrigation water withdrawls on brown trout (Salmo trutta) and two species of benthic invertebrates in a typical southern Michigan stream. Michigan State University, East Lansing, MI, USA.

Harrelson, C.C., Rawlins, C.L., Potyondy, J.P., 1994. Stream channel reference sites: an illustrated guide to field technique. General Technical report RM-245. Rocky Mountain Forest and Range Experimental Stationm, Fort Collins.

Hesse, L.W., Sheets, W., 1993. The Missouri River hydrosystem. Fisheries 18 (5), 3-12.

HR Wallingford, 1997. User Manual, vol. 2. Hydraulic Unit Reference, Halcrow/HR, Wallingford.

INAG, 1999. Estudo experimental para a definição do caudal ecológico do rio Lima-2 $2^{\circ}$ Relatório de progresso, November 1999.

Lambert, T.R., 1987. Development of habitat suitability crireia for trout in the KINGS RIVER Basin, California. Final Report for the Pacific Gas and Electric Company, California, USA.

Langler, J.G., Smith, C., 2001. Effects of habitat enhancement on 0 -group in a lowland river. Regulated rivers. Res. Manage. 17, 677-686.

Lubinski, K., 1992. A conceptual model of the Upper Mississippi River ecosystem. Pages 129-151 in U.S. Fish and Wildlife Service operating plan for the Upper Mississippi River system long-term resource monitoring program. Environmental Management Technical Center EMTC91-P002, Onalaska, WI. 179 pp.

Manly, B.F.J., Mcdonald, D.L., Thomas, 1993. Resource Selection by Animals: Statistical Design and Analysis for Field Studies. Chapman and Hall, London, UK, 175 pp.

Milhous, R.T., 1999. History, theory, use, and limitations of the physical habitat simulation system. Ecohydraulics Midcontinent Ecological Science Center, U.S. Geological Survey, Fort Collins, CO.

Morhardt, J.E., Mesick, C.F., 1988. Behavioral carrying capacity as a possible short term response variable. Hydro Rev. 7 (2), 32-40.

Nakagiri, N., Tainaka, K., Tao, T., 2001. Indirect relation between species extinction and habitat destruction. Ecol. Model. 137, $109-118$. 
National Research Council, 1992. Water Transfers in the West: Efficiency, Equity, and the Environment. National Academy Press, Washington, DC.

Ney-Nifle, M., Mangel, M., 1999. Species-area curves based on geographic range and occupancy. J. Theor. Biol. 196, 327-342.

Noss, R.F., Murphy, D.D., 1995. Endangered species left homeless in sweet home. Conserv. Biol. 9, 229-231.

Patten, B.C., Straškraba, M., Jorgensen, S.E., 1997. Ecosytems emerging: 1. Conserv. Ecol. Model. 96, 221-284.

Payne, T.R., 1998. User's Manual: RHABSIM 2.0-Riverine Habitat Simulation Software for DOS and Windows. T.R. Payne \& Associates, Arcata, CA.

Pilcher, M.W., Copp, G.H., 1997. Winter distribution and habitat use by fish in a regulated lowland river system of South-East England. Fish. Manage. Ecol. 4, 199-215.

Preissmann, A., 1960. Propagation des intumescenes dans les canaux et rivières. In: 1er congress de l'Assoc. Francaise de Calcul, Grenoble.

Raleigh, R.F., Zuckerman, L.D., Nelson, P.C., 1986. Habitat suitability index models and stream flow suitability curves: brown trout, revised. U.S. Fish. Wild. Ser. Biol. Rep. 82, 10-124.

Reyjol, Y., Lim, P., Belaud, A., Lek, S., 2001. Modelling of microhabitat used by fish in natural and regulated flows in the river Garonne (France). Ecol. Model. 146, 131-142.

Scheidegger, K.J., Bain, M.B., 1995. Larval fish distribution and microhabitat use in free-flowing and regulated rivers. Copeia $1,125-135$.

Southwood, T.R.E., 1977. Habitat, the templet for ecological strategies? J. Anim. Ecol. 46, 337-365.

Stalnaker, C.B., Bovee, K.D., Walddle, T.J., 1995. Importance of the temporal aspects of habitat hydraulics to fish populations studies. Regul. River: Res. Manage. 12, 145153.

Straškraba, M., Jorgensen, S.E., Patten, B.C., 1999. Ecosytems emerging: 2. Dissip. Ecol. Model. 117, 3-39.

Ward J.V., Stanford J.A., 1983. The serial discontinuity concept of lotic ecosystems. In: Fontaine, T.D., Bartell, S.M. (Eds.), Dynamics of Lotic Ecosystems. Ann Arbor Sciences, Ann Arbor, MI, pp. 29-42. 